\title{
Artigos de resenha
}

\section{Publicações da FUNAG}

PINTO, Denis Fontes de Souza. OCDE: uma visão brasileira. Brasília: FUNAG, 2000; 170 p. (coleção "Curso de Altos Estudos do Instituto Rio Branco")

HOLANDA, Francisco Mauro Brasil de. O gás natural no Mercosul: uma perspectiva brasileira. Brasília: FUNAG, 2001; 175 p. (coleção "Curso de Altos Estudos do Instituto Rio Branco")

CUNHA, João Solano Carneiro da. Timor Leste: origens e evolução. Brasília: FUNAG, 2001; 246 p. (coleção "Curso de Altos Estudos do Instituto Rio Branco")

A Fundação Alexandre de Gusmão (FUNAG) é uma fundação vinculada ao Itamaraty. Instituída em 1971, está voltada para a discussão e a divulgação de questões ligadas às relações internacionais e à política externa brasileira, através da promoção de estudos e pesquisas, a realização de foros de discussão e reflexão, bem como a publicação de obras que são referência obrigatória à comunidade especializada em Relações Internacionais do Brasil e que auxiliam o leitor não especializado na compreensão dos desafios da inserção do Brasil no contexto mundial. Entre as publicações da FUNAG, encontram-se, por exemplo, algumas séries de documentos oficiais, como a Resenha de Política Exterior do Brasil, que reúne desde 1974 documentos diplomáticos publicados pelo Itamaraty, essenciais para o acompanhamento da prática diplomática brasileira. A série "Cadernos do IPRI" é uma coleção de pequenas monografias sobre a política exterior brasileira e a cena internacional contemporânea, organizada pelo Instituto de Pesquisa de Relações Internacionais, órgão da FUNAG. "Política exterior do Brasil", por sua vez, agrupa títulos específicos sobre o assunto, entre os quais Temas de Política Externa II, organizado por Gelson Fonseca Júnior e Sérgio H. N. de Castro, e o utilíssimo A palavra do Brasil nas Nações Unidas (1946-1995), que reúne os pronunciamentos brasileiros nas sessões de abertura da Assembléia Geral da ONU, acompanhados das preciosas notas de contextualização histórica preparadas pelo Embaixador Luiz Felipe Seixas Corrêa.

Os títulos que encabeçam este artigo de resenha são os últimos lançamentos da "Coleção Altos Estudos", outra importante coleção publicada pela FUNAG, que reúne, desde 1998, as melhores teses dos participantes do Curso de Altos Estudos (CAE) do Instituto Rio Branco. Com essas três novas publicações, a Coleção passa a contar com 15 títulos. O CAE é promovido duas vezes ao ano, 
constituindo uma etapa no processo de progressão funcional na carreira diplomática. Ao concluir o Curso, os diplomatas em estágio avançado na carreira devem elaborar uma tese que resulte em subsídio para a formulação da política exterior do Brasil. Vê-se logo, pois, a extrema relevância desses trabalhos, sendo a iniciativa de colocálos à disposição do público interessado extremamente bem vinda. Sem dúvida, não devemos esquecer do lugar institucional a partir do qual "falam" seus autores. Essa característica da Coleção em nada a desvaloriza, mas, ao contrário, ajudanos a compreender os parâmetros valorativos que guiam a ação do Itamaraty e como a instituição percebe os constrangimentos aos quais deve fazer face.

O livro de Denis Fontes de Souza Pinto, OCDE: uma visão brasileira, trata, basicamente, da oportunidade e da conveniência de uma eventual adesão brasileira à OCDE (Organização para a Cooperação Econômica e o Desenvolvimento). Não há como ignorar o impacto da atuação e a influência do quadro normativo elaborado e implementado pelos países membros da OCDE países de maior desenvolvimento econômico - sobre a ordem econômica mundial. A OCDE reúne os atores internacionais de maior peso econômico e seus debates e documentos acabam tendo grande influência em outros foros, como a Organização Mundial do Comércio. Ou seja, a tendência do "padrão OCDE" a se universalizar faz com que a Organização ganhe grande relevância, inclusive para aqueles países que dela não fazem parte. O Brasil tem status de observador desde 1990 e optou por um enfoque pragmático de cooperação e aproximação seletiva, buscando intensificar sua atenção e contato com os comitês da OCDE cujas agendas estejam ligadas a interesses específicos brasileiros.

"Fica patente", afirma acertadamente Souza Pinto na conclusão de seu trabalho, "que o Brasil deve utilizar sua presença na OCDE, de forma pragmática, para melhor inserir-se na cena internacional". E completa: "Não parece haver, no momento, alternativa a esse encaminhamento da questão. Deve-se, entretanto, ter em mente que status de observador pode ser encarado de maneira mais positiva e não necessariamente restrito a uma postura passiva, reativa. Tendo em vista a flexibilização das normas da Organização, o papel de observador é muito decorrente da intensidade da participação de cada país, de sua atuação nos trabalhos dos comitês. Pode-se construir esse papel, o que vem a respaldar o acerto da política brasileira de aproximação gradual".

As preocupações com o suprimento energético no Brasil não constituem novidade, mas certamente ganharam uma visibilidade sem precedentes em 2001 em conseqüência do quase esgotamento do potencial hidrelétrico em algumas regiões do país. Portanto, chega em mais do que boa hora a publicação de $O$ gás no Mercosul: uma perspectiva brasileira, de Francisco Mauro Brasil de Holanda. No mundo inteiro, a utilização do gás natural vem se incorporando cada vez mais como uma alternativa energética importante por diversos fatores, entre os quais devem-se contar as crescentes preocupações de ordem ambiental (o desastre 
nuclear de Chernobyl contou em muito para que se buscasse fontes energéticas mais seguras) e os avanços tecnológicos na área de prospecção - que representaram um aumento importante da exploração de reservas gasíferas -, e na área de transporte via dutos. O gás natural é o insumo energético que tem tido o maior crescimento relativo no mundo.

O gás no Mercosul: uma perspectiva brasileira avalia os elementos que condicionam e orientam a incorporação à matriz energética brasileira de suprimentos de gás natural provenientes da Bolívia e da Argentina, atentando para as variáveis políticas e econômicas desse processo e suas eventuais implicações para a política brasileira de integração regional. O livro começa descrevendo os aspectos gerais dos sistemas energéticos contemporâneos. Estuda, em seguida, o "perímetro gasífero sul-americano", de onde o Brasil deverá importar a maior parcela de gás natural, e analisa os fatores que viabilizaram o ainda incipiente, mas progressivo, processo de integração gasífera do Brasil com a Argentina e a Bolívia. Identifica e discute, por fim, os impactos da integração gasífera no Cone Sul na integração regional em que se insere. As conclusões do autor são claras: "Para o Brasil, a opção do gás natural do Cone Sul é a que melhor permite conciliar objetivos de suprimento doméstico com a criação de renda e investimento na sub-região. ... O Brasil deve exercer na integração gasífera no Cone Sul uma influência compatível com o peso de sua economia, a maturidade assumida por suas instituições políticas e a consistência de sua ação externa. É um desafio e uma oportunidade que valem a pena."

João Solano Carneiro da Cunha, em A questão de Timor-Leste: origens e evolução, traça um panorama bastante completo de um tema que permaneceu pendente durante mais de duas décadas na agenda da ONU e que assumiu proporções candentes a partir dos anos noventa. $\mathrm{O}$ estudo dá uma visão bastante ampla do processo frustado e muitas vezes violento de descolonização do TimorLeste, que se inicia em 1974, pouco após a Revolução dos Cravos em Portugal. O autor mostra a longa trajetória desse território insular asiático de $19.000 \mathrm{~km}^{2}$, desde a sua ocupação militar pelos indonésios, em dezembro de 1975, até o início da transição para a independência, formalizada em 1999, com a revogação do instrumento legal emanado do governo indonésio que estabelecera a anexação do território da ex-colônia portuguesa como a $27^{\mathrm{a}}$ província da Indonésia, em julho de 1976.

A questão de Timor-Leste... está dividido em cinco capítulos. Nos quatro primeiros analisa o papel e a perspectiva dos principais atores envolvidos no problema timorense: Portugal, Indonésia, os timorenses, a ONU, outras organizações governamentais e não governamentais. No último capítulo do livro, que ainda conta com um posfácio, o autor tece comentários a propósito da diplomacia brasileira para o Timor-Leste. Segundo Carneiro da Cunha, nos últimos 25 anos, a postura do Itamaraty transitou de um claro alheamento, que coincidia com a pouca 
visibilidade internacional que o problema timorense desfrutava, a uma presente cautela, demonstrada, por exemplo, no seio da Comunidade dos Países de Língua Portuguesa (CPLP), onde a adesão do Timor-Leste tem sido defendida com veemência por Portugal. Teme o governo brasileiro, explica o autor, associar-se a uma iniciativa nitidamente inspirada na estratégia portuguesa de pressão ostensiva sobre a Indonésia. Sem dúvida, o argumento é coerente com a histórica prudência e pragmatismo de nosso Ministério das Relações Exteriores. Por outro lado, talvez não seja demais considerar o quanto a sociedade brasileira tem se modificado graças ao exercício da democracia e ao fácil acesso à informação que nos é trazido pela globalização. Definitivamente, não se trata mais de focalizar atenções nos problemas que acontecem "no longínquo e pouco significativo território de Timor-Leste". Nos últimos anos a opinião pública brasileira se manifestou claramente em favor do povo timorense e cobrou uma atitude mais presente e cooperativa do Itamaraty. É verdade, os apelos não caíram no vazio. Mas, estaria fora de propósito esperar um comportamento mais ativo de uma diplomacia que proclama buscar uma participação mais protagônica do Brasil na esfera internacional?

Norma Breda dos Santos 